\title{
Badlands and environmental change
}

\section{Milica Kasanin-Grubin, Belgrade}

\section{Introduction}

Badlands develop in many climatic regions and on a wide range of soils and bedrock (BRYAN \& YAIR 1982; HowARD 1994). The one general characteristic of badlands, regardless of location, is the presence of intensely dissected landforms accompanied by steep slopes, rills, gullies, and frequently, extensive pipe or tunnel erosion (Fig. 1a, b, c, d).

Badlands are often considered to be ideal field «laboratories» because their rapid formation allows close investigation of geomorphic processes (BRYAN \& YAIR 1982). However, badlands can also be seen as ideal areas for furthering understanding of the scale and impact of environmental change, a factor which generally lies at the origin of badland initiation. Badland development is either caused by land use change, such as land clearance due to agricultural development or due to overgrazing, or by natural events like tectonic activity or climatic change (Table 1 ).

Badlands exist under different climatic conditions. GALLART et al. (2002) distinguishes between badlands in arid (precipitation $<200 \mathrm{~mm}$ ), semi-arid (precipitation $200-700 \mathrm{~mm}$ ) and humid climates (precipitation $>700 \mathrm{~mm}$ ), each with a distinct set of processes, not least due to the differing presence of vegetation. In arid climates which do not sustain vegetation, geomorphic processes are controlled by bedrock and regolith properties, in semi-arid climates badland evolution confines plant growth by limiting water availability in thin regoliths, especially on south-facing slopes, while in badlands in humid climates, freezing rather than dryness, is important for plant growth (GALLART et al. 2002).

Arid and semi-arid climates are most often associated with badlands, however, not all landscapes in this climate develop into badlands, and badlands can form in different climates as well. For this reason, fundamental attention should be given to badland materials (CAMPBell 1997). In badland areas with two or more different lithologies, erosion rates, slope properties and processes differ. This particular phenomenon was highlighted in the description by Sснuмm (1956) of the different processes involved in the Brule and Chadron formations of the South Dakota Badlands, USA. It has also been discussed in research on differences between calanchi and biancana in badlands in Italy. Calanchi, which evolve rapidly, have steep rilled and gullied slopes, with mass movement as a main process on the side-slopes. Biancana, on the other hand, have gentler slopes with equally active surface and subsurface networks (pipes and subsurface cracks). They are characterised not only by rill erosion, but by mass movement and sheet wash as well (AleXANDer 1982). Calanchi, which are usually much larger landforms, generally form in coarser sediments like clayey silts and sandy clayey silts, while smaller dome type biancana have a very high clay content (BATTAGLIA et al. 2002; TORRI \& BRYAN 1997). Biancana sediments also have a higher Na content (AleXANDer 1982; Battaglia et al. 2002). BatTAGLia et al. (2002) found that although swelling clay content is roughly the same in materials from both landforms, the weathering profiles differ greatly: while they are only a few centimetres thick on biancana, a thick weathered profile is characteristic of calanchi (VITTORINI 1977 in BatTAgLia et al. 2002).

As mentioned above, badlands mostly develop in clay-rich lithologies. The relation of specific physical and chemical properties of these materials to erosion processes has been demonstrated in many studies (e.g. Bowyer-Bower \& Bryan 1986; Bryan et al. 1978; Bryan et al. 1984; Gerits et al. 1987; Hodges \& BRYAN 1982; IMESON et al. 1982; Oostwoud WiJdENES \& ERgENZINGER 1998; YaIr et al. 1980). Properties such as shrink-swell capacity, slaking potential and dispersivity are controlled by soil texture, clay mineralogy and chemistry, thus strongly influencing the timing and location of runoff generation and the relative significance of surface and subsurface erosional processes (rill erosion and micro-piping). For this reason, KASANIN-Grubin (2006) and Kasanin-Grubin \& Bryan (2007) have argued for the controlling factor role that lithological properties, and in particular clay mineralogy, play in badland hillslope processes and especially in rill development.

The main purpose of this article is to summarize the existing knowledge on badlands as a sensitive indicator of environmental change. Using a laboratory experiment as an example, a clear link is made between lithological properties of badland materials and environmental change.

\section{Climatic conditions: temporal and seasonal change}

Climate influences vegetation cover, soil development and weathering processes. Erosion effectiveness of rainfall depends on the intensity, duration, and size 


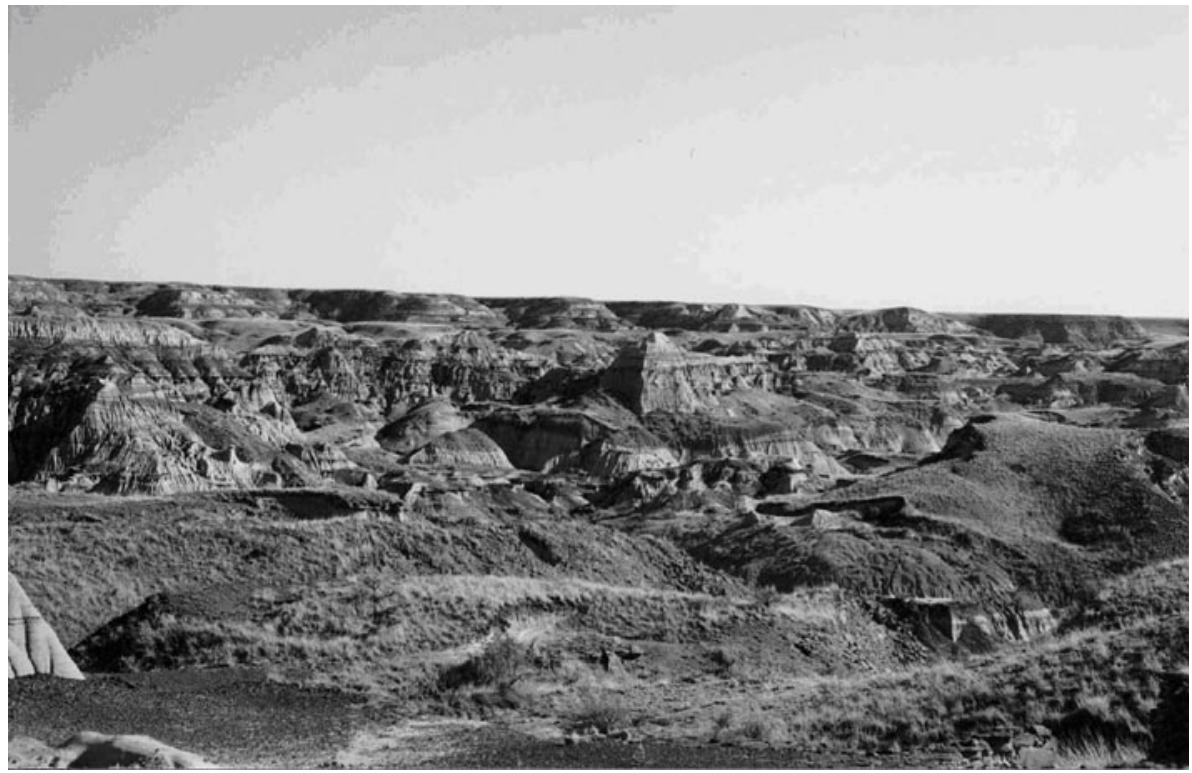

Fig. 1a: Dinosaur Badlands, Alberta, Canada, 2001

Photo: M. KASANIN-GrUbIN

Dinosaur Badlands, Alberta, Kanada, 2001

Badlands de Dinosaur, Alberta, Canada, 2001

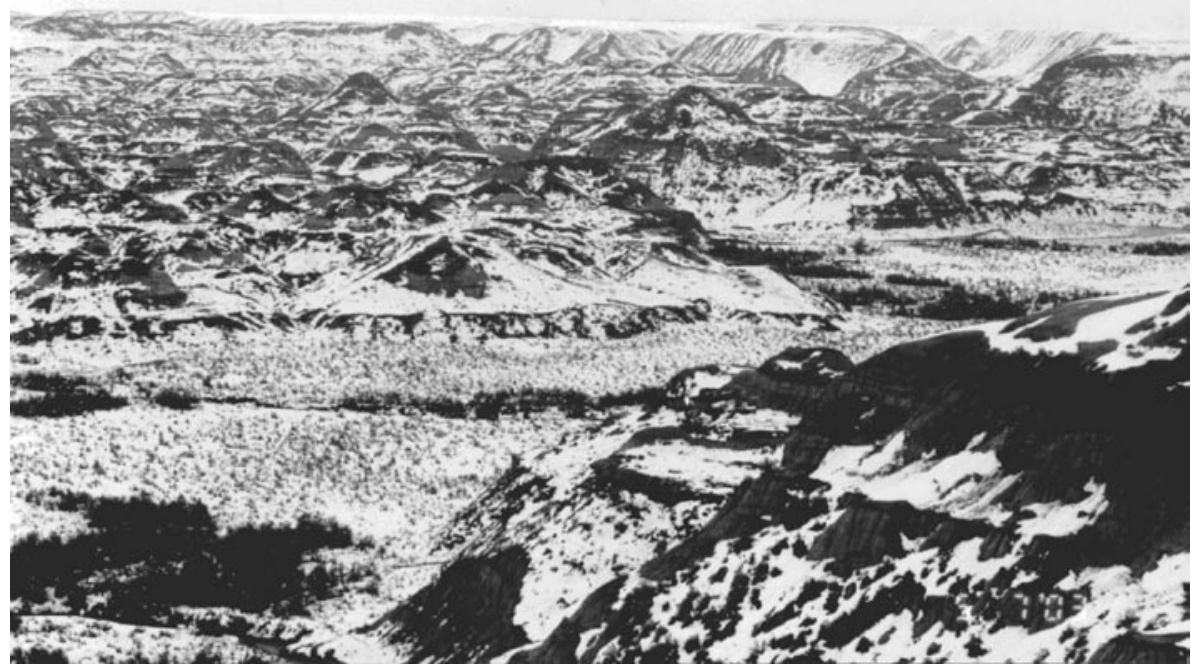

Fig. 1b: Dinosaur Badlands, Alberta, Canada, 2003

Photo: M. KaSANIN-GrubIN

Dinosaur Badlands, Alberta, Kanada, 2003

Badlands de Dinosaur, Alberta, Canada, 2003 


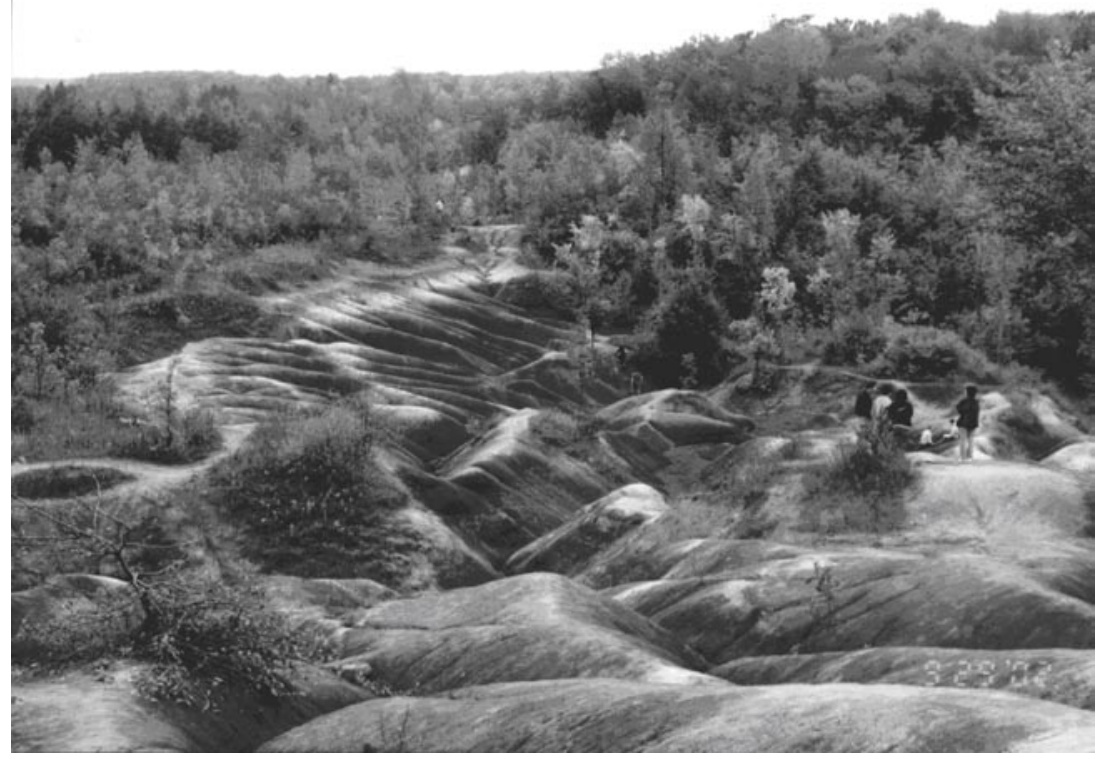

Fig. 1c: Chinguacousy Badlands, Ontario, Canada

Photo: M. KASANIN-Grubin Chinguacousy Badlands, Ontario, Kanada

Badlands de Chinguacousy, Ontario, Canada

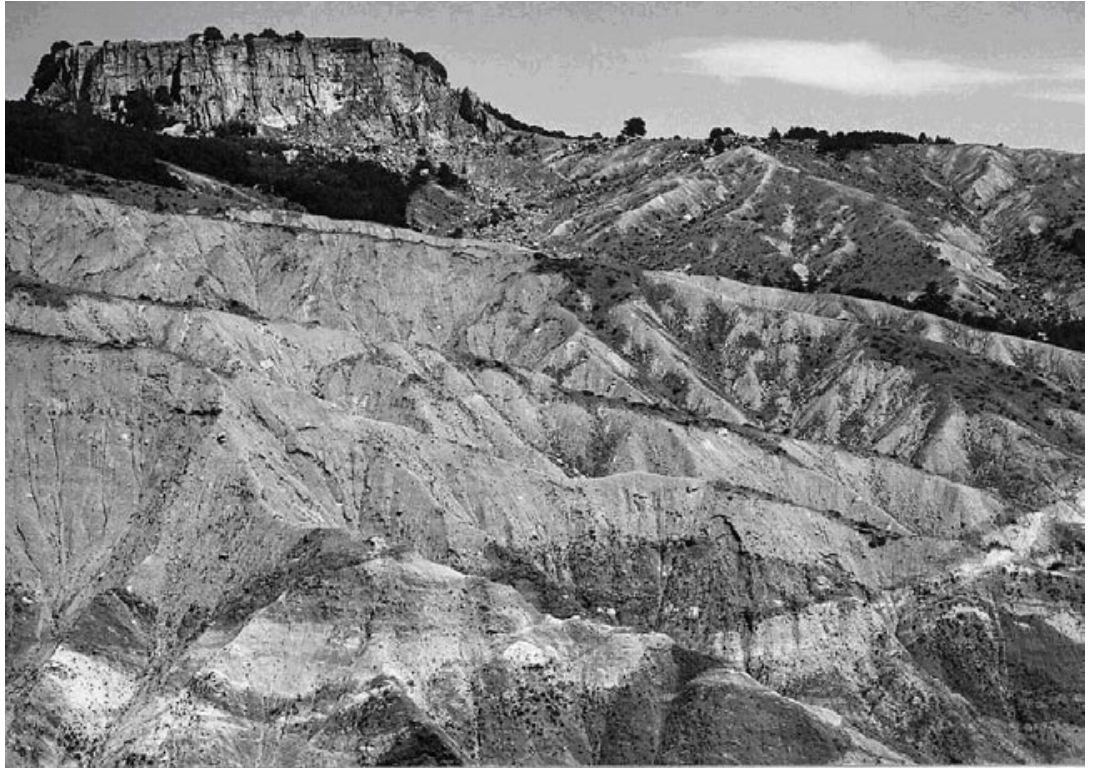

Fig. 1d: Sestino Badlands, Tuscany, Italy

Photo: M. KaSAnIN-Grubin

Sestino Badlands, Toskana, Italien

Badlands de Sestino, Toscane, Italie 


\begin{tabular}{|c|c|c|c|c|c|}
\hline Climate & $\begin{array}{l}\text { Precipitation } \\
(\mathrm{mm})\end{array}$ & Badlands & Lithology & Initiation & Reference \\
\hline Arid & $<200$ & Zin Badlands, Israel & $\begin{array}{l}\text { Calcareous shale, } \\
\text { montmorillonite, kaolinite, } \\
\text { illite, gypsum, pyrite }\end{array}$ & Geological control & $\begin{array}{l}\text { YAIR et al. } \\
(1980)\end{array}$ \\
\hline \multirow{5}{*}{ Semi-arid } & $\sim 300$ & $\begin{array}{l}\text { Vera Badlands, } \\
\text { Spain }\end{array}$ & $\begin{array}{l}\text { Upper Miocene gypsiferous } \\
\text { marls }\end{array}$ & \multirow{3}{*}{$\begin{array}{l}\text { Dissection of valley } \\
\text { controlled by } \\
\text { tectonics }\end{array}$} & \multirow{3}{*}{$\begin{array}{l}\text { CAlvo- } \\
\text { CASES \& } \\
\text { HARvey } \\
(1996)\end{array}$} \\
\hline & $\sim 300$ & $\begin{array}{l}\text { Petrer Badlands, } \\
\text { Spain }\end{array}$ & Upper Cretaceous marls & & \\
\hline & $\sim 300$ & $\begin{array}{l}\text { Monnegre Badlands, } \\
\text { Spain }\end{array}$ & Senonian marls & & \\
\hline & $\sim 330$ & $\begin{array}{l}\text { Dinosaur Park } \\
\text { Badlands, Canada }\end{array}$ & $\begin{array}{l}\text { Cretaceous sandstone, } \\
\text { mudrock }\end{array}$ & $\begin{array}{l}\text { River incision after } \\
\text { deglaciation }\end{array}$ & $\begin{array}{l}\text { BRYAN et } \\
\text { al. (1978); } \\
\text { BRYAN } \\
(1987) ; \\
\text { KASANIN- } \\
\text { GRUBIN } \\
(2006)\end{array}$ \\
\hline & $\sim 500$ & $\begin{array}{l}\text { Tabernas Badlands, } \\
\text { Spain }\end{array}$ & $\begin{array}{l}\text { Upper Miocene deep- } \\
\text { marine mudrock; marls, } \\
\text { shales, turbidites and } \\
\text { interbedded sandstones }\end{array}$ & $\begin{array}{l}\text { Natural, but may be } \\
\text { man-induced because } \\
\text { bedrock is sensitive to } \\
\text { vegetation removal }\end{array}$ & $\begin{array}{l}\text { AlEXANDER } \\
\text { et al. (1994) }\end{array}$ \\
\hline \multirow{4}{*}{$\begin{array}{l}\text { Temperate } \\
\text { humid }\end{array}$} & $\sim 800$ & $\begin{array}{l}\text { Val D’Orcia } \\
\text { Badlands, Italy }\end{array}$ & Pliocene marine clays & $\begin{array}{l}\text { Quaternary } \\
\text { tectonically induced } \\
\text { dissection }\end{array}$ & $\begin{array}{l}\text { TORRI \& } \\
\text { BRYAN } \\
(1997) \\
\end{array}$ \\
\hline & $\sim 800$ & $\begin{array}{l}\text { Vallcebre Badlands, } \\
\text { Spain }\end{array}$ & Cretaceous mudrocks & Mostly man-induced & $\begin{array}{l}\text { REgUes et } \\
\text { al. (1995) }\end{array}$ \\
\hline & $\sim 885$ & $\begin{array}{l}\text { Chinguacousy } \\
\text { Badlands, Canada }\end{array}$ & Ordovician Queenston shale & Land clearance & $\begin{array}{l}\text { KASANIN- } \\
\text { GRUBIN } \\
(2006) \\
\end{array}$ \\
\hline & $\sim 1270$ & $\begin{array}{l}\text { Sestino Badlands, } \\
\text { Italy }\end{array}$ & $\begin{array}{l}\text { Cretaceous deep marine } \\
\text { varicoloured shales }\end{array}$ & Land clearance & $\begin{array}{l}\text { KASANIN- } \\
\text { GRUBIN } \\
(2006)\end{array}$ \\
\hline
\end{tabular}

Tab. 1: Characteristics of some badland areas

Eigenschaften ausgewählter Badlands

Caractéristiques de quelques zones de badlands

distribution of drops, as well as their velocity. The amount and duration of wetting and drying periods influence material infiltration rates, type of erosion processes and weathering processes. However, material properties can change over short time periods between storm events, or on a more regular seasonal cycle due to moisture changes (IMESON \& VERSTRATEN 1988; Regues \& Gallart 2004; Sirvent et al. 1997), frost action or snowmelt (IASIO et al. 2002; PARDINI et al. 1995; Regues et al. 1995).

Temporal changes can produce marked changes in surface characteristics, as described in Schumm \& LusBy (1963) on annual rill formation and obliteration, and seasonal change of processes on the smectite-rich Mancos shale, Colorado, USA. During winter, freezing and thawing transforms the less permeable rilled surface into a highly permeable surface without rills. During spring and summer, compaction of the surface, runoff increase and rills re-establishment can be observed. ScogING (1982) observed significantly less erosion during winter than summer in the Ugijar badlands in SE Spain due to short, but high intensity storms in summer months. It was also noted that the last summer rains flush out dry surface material, reducing the amount of material that is ready for transport by winter rainfalls.

Seasonal changes in material response have been observed by Regues et al. (1995) and Regues \& GALLART (2004) regarding weathering and erosion in the mountainous Vallcebre Badlands of the SE Pyrenees, Spain. Both studies were based on antecedent moisture and bulk density measurements. Physical weathering was found to be strongest during the winter due to frost action; during summer and fall, the material is easily removed and erosion is most active. As a consequence, it appears that the Vallcebre Badlands' materials are 
subject to alternating periods of erosional and weathering activity with conditions being described as stable in autumn and spring and transitional in summer and winter (REgues \& Gallart 2004). These authors also indicate a two-season delay between maximal weathering. Observed erosional response was a consequence of the delay between the season with the strongest weathering and the season with the strongest erosion

Slopes with different aspects have various radiation receipts. They also receive different precipitation inputs, which vary with each storm and are influenced by prevailing wind conditions. Aspect-related differences in slope characteristics are likelier to occur in arid areas because of the more critical nature of moisture conditions here than in areas with abundant moisture (ChurchiLl 1981). In the Brule Formation Badlands, South Dakota, USA, south-facing slopes, which are subjected to more intense wetting and drying, are significantly shorter, steeper and generally straighter in profile than their north-facing counterparts (CHURCHILL 1981). In contrast, the north-facing slopes are densely rilled with deeper regoliths due to deeper infiltration. In the Zin Badlands, Negev, Israel, north-facing slopes have rough, lichen covered surfaces with deep regoliths, while their south-facing counterparts are smoother with greater runoff rates (YAIR et al. 1980). Similarly, in the Dinosaur Park Badlands, Alberta, USA, north-facing slopes retain snow longer and have moister regoliths (HARTY 1984). Despite the fact that the significance of slope aspect as a control factor of erosion processes has been described in these and other areas, it has not been clearly identified whether the erosional and weathering processes are predominantly climate driven or if the critical variable are the lithological physico-chemical properties.

\section{Lithological properties: clay minerals and weathering}

Most badland lithologies are clay-rich materials and their behaviour is controlled by the type and amount of clay minerals present. Clay minerals are fine-grained with size particles $<2 \mu \mathrm{m}$. Due to their sheet shape, they have a very large surface area. The clay minerals found predominantly in badland materials are smectite, illite, chlorite and kaolinite.

The properties of active clays change significantly due to weathering at or near the surface as they progressively become exposed (FAULKNER et al. 2000; FinLAYSON et al. 1987). As the crust develops, the physico-chemical properties of the material in the weathered layers change, thereby influencing the activity of the geomorphic processes. Alternation of wetting and drying cycles, presence of joints and fissures and dissolution-crystalli- zation of soluble minerals are the three main influences on mudrock weathering (CANTON et al. 2001). Wettingdrying cycles may cause compaction of the internal structure and there appears to be a significant difference in material response to precipitation depending on whether or not it is followed by freezing (during which more deterioration occurs) (PARDINI et al. 1995).

The weathering profiles of mudrock in the Dinosaur Badlands Park, Alberta, Canada (Hodges \& Bryan 1982), marls from the Guadix Basin Badlands, Spain (Gerits et al. 1987), mudrocks from the Chadron Formation, Utah, USA (HowARD 1994) and mudrocks from the Zin Valley Badlands, Israel (YAIR et al. 1980) have the following typical layers: a) $1-2 \mathrm{~cm}$ thick porous crust with desiccation cracks, leached of highly soluble components; b) $\sim 10 \mathrm{~cm}$ subsurface compact layer rich in micropores; c) $10-40 \mathrm{~cm}$ thick transitional layer with partly weathered shards and d) unweathered material.

The crust characteristics, such as mineralogical and geochemical composition, cracks and thickness of the surface and subsurface layers influence the processes on the hillslope. The type of crust that develops on the exposed material depends on its physico-chemical characteristics and on the magnitude and frequency of precipitation. Intense shrink-swell activity in smectiterich sediments can produce desiccation cracks and a loose «popcorn» regolith that has high macroporosity (IMESON 1986; Schumm 1956). The «popcorn» surface can also form with repeated freezing-thawing cycles and expansion that occurs due to ice crystal growth. Clay swelling can also induce stronger alteration of mudrock than caused with wetting and drying (PARDINI et al. 1995). The "popcorn» surface has been identified in the Chadron formation, South Dakota, USA (Schumm 1956), Dinosaur Park Badlands, Alberta, Canada (Bryan et al. 1978), Vallcebre Badlands, Spain (Regues et al. 1995) and the Val D'Orcia Badlands, Italy (TORrI \& BRYAN 1997). In the Zin Badlands, Israel, the swelling of smectite clays was suppressed due to the presence of kaolinite and calcite. Instead of a typical «popcorn» crust with loose aggregates, a dense crust rich in desiccation cracks with a subsurface coarse shard layer developed (YaIR et al. 1980). A similar crust developed on marls in badlands in SE Spain (CANTON et al.2001) and on smectite-poor shales in the Chinguacousy Badlands, Canada (KASA-NIN-GruBIN 2006).

\section{Lithological properties and climatic conditions: laboratory experiment}

Kasanin-Grubin \& Bryan (2007) investigated differences in appearance of surface conditions in the Badlands of Dinosaur Park, Canada, during research 
which was carried out in May, 2001 and May, 2003 (Fig. $1 \mathrm{a}, \mathrm{b} ; 2 \mathrm{a}, \mathrm{b})$. On both occasions, the geometric characteristics of rills and rills systems were measured. Even though the number of sites in 2001 was substantially smaller than in 2003, differences in geometric properties were still evident. Rill width and width/depth ratio on mudrock slopes decreased, while rill depth increased during the two years. The limited number of sites investigated and the high standard deviation of the 2001 data prevented direct comparison of rill network properties between the two years. However, field observations allowed the conclusion to be drawn that the rill systems on mudrock appeared to not only be more incised but also denser and characterised by longer first order channels.

Besides the form of rill systems, the difference in appearance of the surface crust on the mudrock slopes between 2001 and 2003 was even more striking (Fig. 2b). In 2001, conspicuous "popcorn» surface crust characterized many of the mudrock surfaces. It formed on active smectite-rich clays and led to great local variation in microrelief and material properties (DE Boer \& CAMPBell 1990). In 2003, the "popcorn» crust was almost completely absent; surfaces were sealed, had less microrelief and were denser, with wider and deeper desiccation cracks.

Thus it appears that for Alberta mudrocks, although climatic seasonal variation may not appear to be particularly significant during an average year, dramatic changes can occur under extreme precipitation conditions. This includes the transformation of the surface from its «popcorn» characteristic to a dense, flat and compacted surface. Similarly, in Mediterranean climates, seasonal distribution of precipitation was found to be more important than the total amount of rain (YAALON 1997). For example, on similar material in the Petrer Badlands, Spain, Calvo-Cases \& Harvey (1996) observed more changes between seasons than between years.

If the Alberta mudrocks are susceptible to «seasonal» changes, then the same could be assumed for smectiterich shales in other regions due to their similar mineralogical composition. To test this assumption, KASANINGrUBIN (2006) tested smectite-rich and smectite-poor lithologies by means of weathering experiments. Mudrock shards (average $1 \times 1 \times 0.5 \mathrm{~cm}$ ) were placed in circular aluminium sample trays (radius $=12.5 \mathrm{~cm}$, depth $4 \mathrm{~cm}$ ). They were subjected to 10 cycles of simulated rainfall at $45 \mathrm{mmh}^{-1}$ intensity with duration ranging from 10 to $60 \mathrm{~min}$.

In the smectite-rich lithologies a marked difference in surface crust and desiccation crack development was noticed (Fig. 3a). The shard structure with defined margins was maintained throughout the experiment under rainfall durations of 10 and 20 minutes. This could be due to shard swelling potential being limited by water availability and the short duration of the wetting period. During drying cycles, minute cracks of $<1 \mathrm{~mm}$ in width often appeared on the shard surfaces. In contrast, the effect of water availability could be seen on the samples subjected to 50 and 60 minutes of rainfall. Here, maximum swelling appeared after the first cycle of rainfall (Fig. 3a). After this swift swelling, samples became unstable and dispersive, and after the third rainfall cycle, dispersion became dominant, resulting in flatter surfaces, thinner crust development and narrower desiccation cracks. From the weathering experiments it would seem that even rainfall of very short duration (10-20 min) can lead to swelling of clay minerals during wetting and formation of «popcorn» surface during drying periods. During subsequent wetting-drying periods, the crust becomes flatter and denser, and desiccation cracks become wider and deeper. Depending on size, continuity and reappearance after wetting, cracks can become flowpaths and may evolve into rills. The rate at which cracks reappear after sealing is very important for runoff generation, particularly in typical infrequent rainstorms of low intensity and duration (BRYAN et al. 1978).

In the smectite-poor materials there was no apparent difference in samples as a result of rainfall duration (KaSANIN-Grubin 2006). When exposed to rainfall, smectite-poor shale shards broke apart after each drying cycle (Fig. 3b). During repeated cycles of wetting and drying, large smectite-poor shards broke down into smaller shards due to differential swelling of illite and chlorite. Once they were reduced to tiny, flaky shards $(0.5 \mathrm{~cm} \times 0.2 \mathrm{~cm})$, the surface became compacted. As indicated above, this process appears to be characteristic of Mancos shale in Utah (FAM \& DusSEAUlt 1998). The Mancos shale decomposes after a few tens of hours with only slight swelling into flaky shards (HowARD 1997). These materials are salt-rich and each time shards disintegrate they yield a yellowish liquid rich in $\mathrm{Na}$ and $\mathrm{Ca}$ sulphates (LARONNE 1981). If salt leaching does not occur, shard disintegration will not occur (Howard 1997). The mixed-layer non swelling clay minerals can cause pressure to increase under repeated wetting and drying conditions, possibly leading to brittle failure of material (WUST \& MCLANE 2000). Cracks that form during slaking promote further permeability and expose more rock surface to water (SADISUN et al. 2005).

Furthermore, smectite-rich and smectite-poor lithologies appear to differ not only in their response to wetting periods, but to drying periods as well (KASANINGrUBIN 2006). Lithologies that have thin regoliths, like Alberta badland sandstone and smectite-poor litholo- 


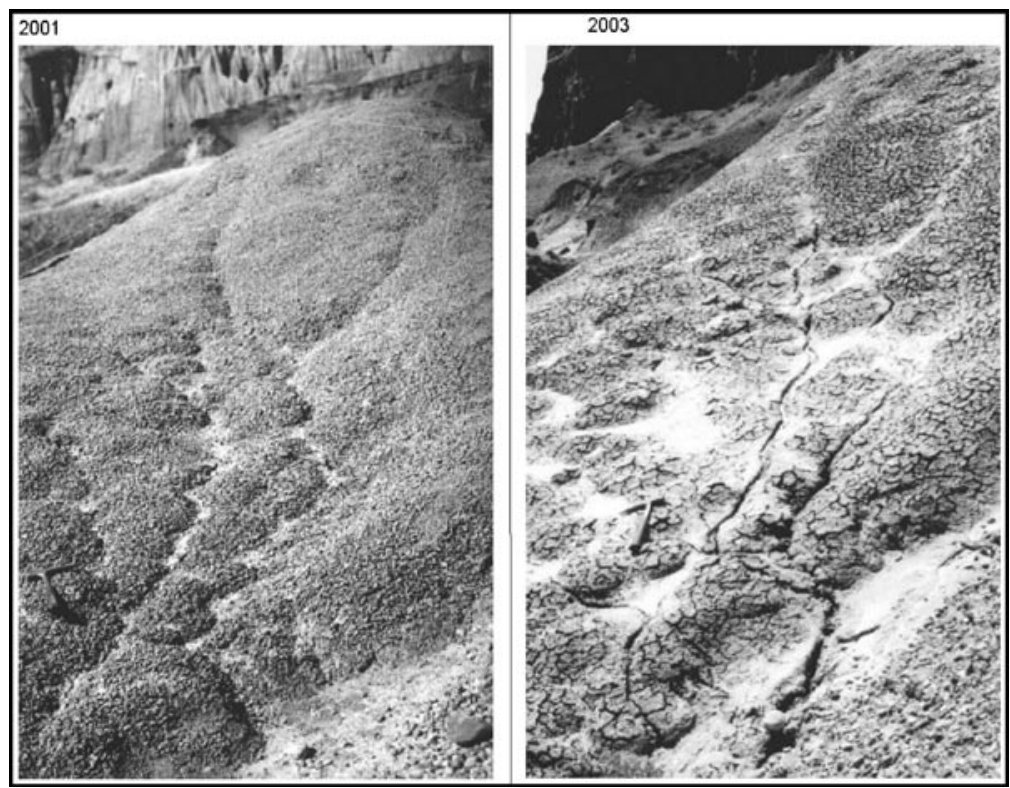

Photos: M. KASANINGRUBIN

Fig. 2a: Difference between rill network and surface characteristics on the same site in 2001 (left) and 2003 (right) Unterschied zwischen Rillsystem und Oberflächeneigenschaften am selben Ort, 2001 (links), 2003 (rechts)

Différence entre le réseau de rigoles de ruissellement et les caractéristiques de surface sur le même site en 2001 (gauche) et 2003 (droite)

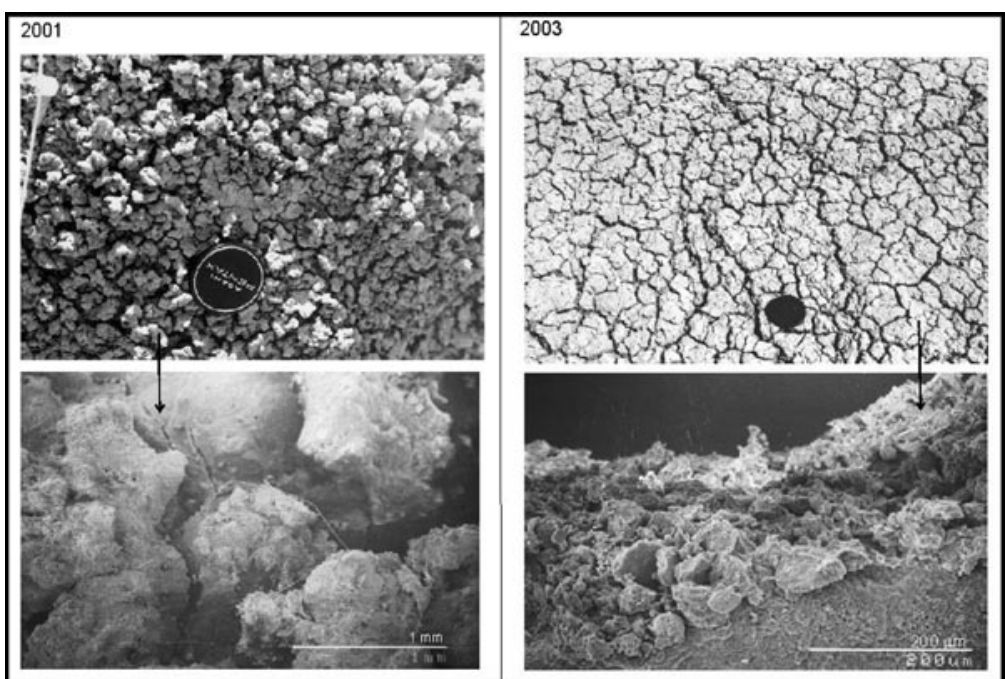

Photos: M. KASANinGRUBIN

Fig. 2b: Photos and SEM images of «popcorn» surface in 2001 (left) and surface crust in 2003 (right)

Fotos und SEM (Scanning Electron Microscope) Aufnahmen einer «Popkorn»-Oberfläche, 2001 (links) sowie einer Oberflächenkruste, 2003 (rechts)

Photographies et images SEM (Scanning Electron Microsope) d'une surface en «popcorn» en 2001 (gauche) et croûte de surface en 2003 (droite) 


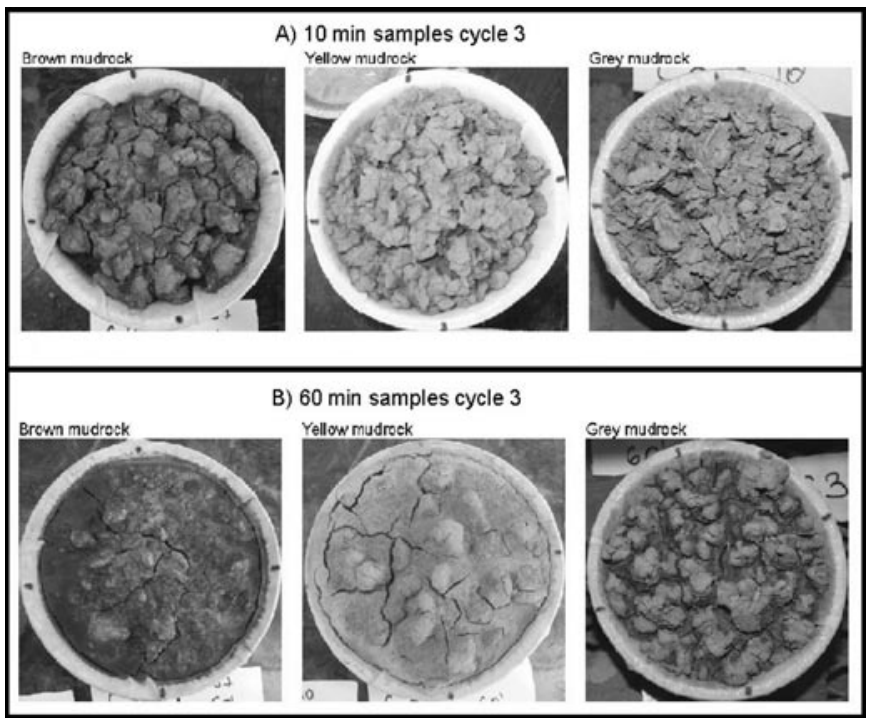

Photos: M. KasAnINGRUBIN

Fig. 3a: Incremental weathering experiment on smectite-rich lithologies. Samples subjected to three wetting (45 mainfall intensity) cycles of a) $10 \mathrm{~min}$. and b) $60 \mathrm{~min}$. rainfall.

Stufenweises Verwitterungsexperiment mit Smektit-reichen Gesteinen. Die Proben wurden drei aufeinanderfolgenden Beregnungen (45 $\mathrm{mm} \mathrm{h}^{-1}$ Niederschlagsintensität) von jeweils a) 10 Min. und b) 60 Min. unterworfen.

Expérience climatique incrémentale sur des lithologies reiches en smectite. Echantillons sujets à trois cycles d'arrosage (intensité de pluie de $45 \mathrm{~mm} \mathrm{~h}^{-1}$ ) de a) $10 \mathrm{~min}$. et b) $60 \mathrm{~min}$. de pluie.

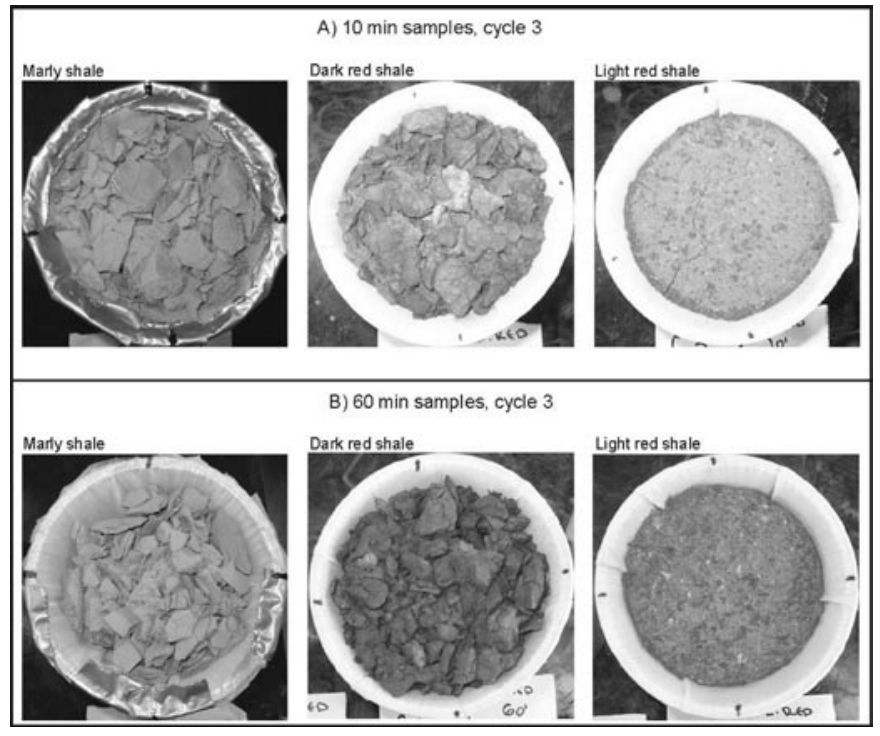

Photos: M. KaSANINGRUBIN

Fig. 3b: Incremental weathering experiment on smectite-poor lithologies. Samples subjected to three wetting (45 $\mathrm{mm} \mathrm{h}^{-1}$ rainfall intensity) cycles of a) $10 \mathrm{~min}$. and b) $60 \mathrm{~min}$. rainfall. Stufenweises Verwitterungsexperiment mit Smektit-armen Gesteinen. Die Proben wurden drei aufeinanderfolgenden Beregnungen (45 $\mathrm{mm} \mathrm{h}^{-1}$ Niederschlagsintensität) von jeweils a) 10 Min. und b) 60 Min. unterworfen.

Expérience climatique incrémentale sur des lithologies pauvres en smectite. Echantillons sujets à trois cycles d'arrosage (intensité de pluie de $45 \mathrm{~mm} \mathrm{~h}^{-1}$ ) de a) $10 \mathrm{~min}$. et b) $60 \mathrm{~min}$. de pluie. 
gies, do not respond to moisture input/output variations. In contrast, smectite-rich lithologies release up to 4 times more sediments when moisture inputs occur over long periods $(60 \mathrm{~min})$ with drying periods in between than during short rainfalls $(10 \mathrm{~min})$ of same intensity. This indicates the importance of drying for smectite-rich materials which can differ with slope orientation. Furthermore it also implies more profound differences that occur with sensu stricto seasonal climatic changes. Even more importantly, this observation highlights the importance of the response of the material to climatic variations, a response which does not necessarily occur on a regular cycle.

\section{References}

Alexander, D. (1982): Difference between «calanchi» and «biancane» badlands in Italy. - In: BrYAN, R. \& A. Yair (eds): Badland geomorphology and piping. - Norwich: Geo Books: 71-87.

Alexander, R.W., Harvey, A.M., Calvo, A., James, P.A. \& A. CERDA (1994): Natural stabilization mechanisms on badland slopes: Tabernas, Almeria, Spain. - In: Millington, A.C. \& K. Pye (eds): Environmental change in drylands: biogeographical and geomorphological perspectives. - Chichester: John Wiley \& Sons Ltd.: 85-111.

Battaglia, S., Leoni, L. \& F. Sartori (2002): Mineralogical and grain size composition of clays developing calanchi and biancane erosional landforms. - In: Geomorphology 49: 153-170.

BOWYER-BOWER, T.A.S. \& R.B. BRYAN (1986): Rill initiation: concept and experimental evaluation on badland slopes. - In: Zeitschrift für Geomorphologie, N.F., 60: 161-175.

Bryan, R.B, Yair, A. \& W.K. Hodges (1978): Factors controlling the initiation of runoff and piping in Dinosaur Provincial Park Badlands, Alberta, Canada. - Zeitschrift für Geomorphologie, N.F., Supplement Band 29: 151-168.

Bryan, R.B. (1987): Processes and significance of rill development. - In: BrYAN, R.B. (ed.): Rill erosion; processes and significance. - Catena, Supplement 8: $1-15$.

BRYAN, R.B. \& A. YAIR (1982): Badland geomorphology and piping. - Norwich: Geo Books.

Bryan, R.B., Imeson, A.C. \& I.A. Campbell (1984): Solute release and sediment entrainment on microcatchments in the Dinosaur Park Badlands, Alberta, Canada. - In: Journal of hydrology 71: 79-106.

Calvo-Cases, A. \& A.M. Harvey (1996): Morphology and development of selected badlands in Southeast Spain: implications of climatic change. - In: Earth surface processes and landforms 21:725-735.

CAMPBEll, I.A. (1997): Badlands and badland gullies. - In: Thомаs, D.S.G. (ed.): Arid zone geomorphology: process, form and changes in drylands. $-2^{\text {nd }}$
edition,Chichester: John Wiley \& Sons Ltd.: 261291.

Canton, Y., Sole-Benet, A., Queralt, I. \& R. Pini (2001): Weathering of a gypsum-calcareous mudstone under semi-arid environment at Tabernas, SE Spain: laboratory and field-based experimental approaches. - In: Catena 44: 111-132.

Churchill, M. (1981): Aspect-related differences in badlands slope morphology. - Annals of the Association of American Geographers 71, 3: 374-388.

De Boer, D. \& I.A. CAmpbell (1990): Runoff chemistry as an indicator of runoff sources and routing in semi-arid, badland drainage basins. - In: Journal of hydrology 121:379-394.

FAM, M.A. \& M.B. Dusseault (1998): High-frequency complex permittivity of shales $(0.02-1.30 \mathrm{GHz})$. - In: Canadian geotechnical journal 35: 524-531.

Faulkner, H., Spivey, D. \& R. Alexander (2000): The role of some site geochemical processes in the development and stabilisation of three badland sites in Almeria, Southern Spain. - In: Geomorphology 35: 87-99.

Finlayson, B.L., Gerits, J. \& B. van Wesemael (1987): Crusted microtopography on badland slopes in southeast Spain. - In: Catena 14: 131-144.

Gallart, F., Solé, A., Puigdefàbregas, J. \& R. Lázaro (2002): Badland systems in the Mediterranean. - In: Bull, L.J. \& M.J. KirKBy (eds): Dryland rivers: hydrology and geomorphology of semi-arid channels. - Chichester: John Wiley \& Sons Ltd.: 299-326.

Gerits, J., Imeson, J.M., Verstraten, J.M. \& R.B. Bryan (1987): Rill development and badland regolith properties. - In: Catena, Supplement 8: 141-160.

HarTY, K.M. (1984): The geomorphic role of snow in a badland watershed. - Unpublished M.Sc. thesis, University of Alberta.

Hodges, W.K. \& R.B. Bryan (1982): The influence of material behaviour on runoff initiation in the Dinosaur Badlands, Canada. - In: BryAn, R. \& A. YAIR (eds): Badland geomorphology and piping. - Norwich: Geo Books: 13-46.

Howard, A.D. (1994): Badlands. - In: Abrahams, A.D. \& A.J. PARsons (eds): Geomorphology of desert environments. - London: Chapman \& Hall: 312-242.

HowarD, A.D. (1997): Badland morphology and evolution: interpretation using a simulation model. - In: Earth surface processes and landforms 22:211-227.

iasio, C., Ferrari, G., Galligani, U., Borselli, L. \& D. TORRI (2002): Observations on snowmelt effects on the Northern Apennine shales (Italy). - International Symposium on Snowmelt Erosion and Related Problems, 28-30 March 2001, Oslo, Norway, abstract.

Imeson, A., KwAAD, F.J.P.M. \& J.M. Verstraten (1982): The relationship of soil physical and chemical properties to the development of badlands in Morocco. - In: BRYAN, R. \& A. YAIR (eds): Badland geomorphology and piping. - Norwich: Geo Books: 47-69.

IMESON, A.C. (1986): Investigating volumetric changes 
in clayey soils related to subsurface water movement and piping. - Zeitschrift für Geomorphologie, N.F., 60: 115-130.

Imeson, A.C. \& J.M. Verstraten (1988): Rills on badland slopes: a physico-chemically controlled phenomenon. - In: Catena, Supplement 12: 139-150.

KASANIN-GRUBIN, M. (2006): Influence of clay mineralogy on rill system development on badland hillslopes. - Unpublished PhD thesis, Department of Physical Geography, University of Toronto, Canada.

Kasanin-Grubin, M. \& R.B. Bryan (2007): Lithological properties and weathering response on badland hillslopes. - In: Catena 70: 68-78.

LARonne, J.B. (1981): Mancos shale-associated alluvium. - In: Earth surface processes and landforms 6: 541-552.

Oostwoud Wijdenes, D.J. \& P. Ergenzinger (1998): Erosion and sediment transport on steep marly hillslopes, Draix, Haute-Provence, France: an experimental field study. - In: Catena 33: 179-200.

Pardini, G., Pini, R., Barbini, R., Regues, D., Plana, F. \& F. GALlaRt (1995): Laser elevation measurements of a smectite-rich mudrock following freeze-thawing and wet-drying cycles. - In: Soil technology 8: 161-175. Regues, D. \& F. GAllart (2004): Seasonal patterns of runoff and erosion responses to simulated rainfall in a badland area in Mediterranean mountain conditions (Vallcebre, Southeastern Pyrenees). - In: Earth surface processes and landforms 29, 6: 755-767.

Regues, D., Pardini, G. \& F. Gallart (1995): Regolith behaviour and physical weathering of clayey mudrock as dependent on seasonal weather conditions in a badland area at Vallcebre, Eastern Pyrenees. - In: Catena 25: 199-212.

Sadisun, I.A., Shimada, H., Ichinose, M. \& K. Matsui (2005): Study on the physical disintegration characteristics of Subang claystone subjected to a modified slaking index test. - In: Geotechnical and geological engineering 23: 199-218.

Schumm, S.A. (1956): The role of creep and rainwash on the retreat of badland slopes. - In: American journal of science 254: 693-705.

Schumm, S.A. \& G.C. Lusby (1963): Seasonal variations of infiltration capacity and runoff on hillslopes in Western Colorado. - In: Journal of geophysical research 68, 12: 3655-3666.

ScogING, H. (1982): Spatial variations in infiltration, runoff and erosion on hillslopes in semi-arid Spain. - In: BRYAN, R.B. \& A. YAIR (eds): Badland geomorphology and piping. - Norwich: Geo Books: 89-112.

Sirvent, J., Desir, G., Gutierrez, M., Sancho, C. \& G. BenITo (1997): Erosion rates in badland areas recorded by collectors, erosion pins and profilometer techniques (Ebro Basin, NE-Spain). - In: Geomorphology 18: 61-75. TORRI, D. \& R.B. BRYAN (1997): Micropiping processes and biancana evolution in southest Tuscany, Italy. - In: Geomorphology 20: 219-235.
Wust, R.A.J. \& J. McLANE (2000): Rock deterioration in the Royal Tomb of Seti I, Valley of the Kings, Luxor, Egypt. - In: Engineering geology 58: 163-190.

YAALON, D.H. (1997): Soils in the Mediterranean region: what makes them different? - In: Catena 28: 157-169.

Yair, A., Lavee, R.B., Bryan, R.B. \& E. Adar (1980): Runoff and erosion processes and rates in the Zin Valley Badlands, Northern Negev, Israel. - In: Earth surface processes and landforms 5: 205-225.

\section{Abstract: Badlands and environmental change}

Badlands develop in many climatic regions, on a wide range of soils and in various bedrock types. The physical triggers for development of badlands can be natural, such are tectonic activity and climate change, but more frequently they are human induced, e.g. land clearance to change use of land. The research presented here clearly indicates that clay mineralogy and type and amount of clay in the bedrock play a critical role in the development of surface crust and hillslope morphology and ultimately of badlands. Laboratory experiments on smectite-rich samples subjected to simulated rainfall have established a correlation between phased development of surface crust and desiccation cracks and duration of rainfall. A similar correlation could not be found for smectite-poor materials. In addition, evidence was collected on the different responses of smectite-rich and smectite-poor lithologies to wetting and drying periods. Thus, it appears in particular that drying periods play an important role in badland development on smectite-rich materials, an aspect which is directly linked to slope orientation and strongly sensitive to differences that occur with sensu stricto seasonal climatic changes.

Keywords: badlands, environmental change, lithological properties, clay mineralogy

\section{Zusammenfassung: Badlands und Umweltwandel}

Badlands haben sich in mehreren Regionen entwikkelt, auf einer Vielzahl von Böden und auf verschiedenen Festgesteinen. Die physikalischen Auslöser der Badlandentwicklung können natürlich sein, wie etwa tektonische Aktivität oder Klimawandel, jedoch wird sie häufiger durch den Menschen verursacht, z.B. durch Abholzung aufgrund einer anderen Landnutzung. Diese Arbeit hat klar aufgezeigt, dass die Tonmineralogie, die Tonart und Tonmenge im Festgestein eine entscheidende Rolle bei der Entwicklung einer Oberflächenkruste sowie der Hangmorphologie und letztendlich von Badlands spielen. Experimente im Labor an Smektit-reichen Proben, welche simuliertem Regen ausgesetzt wurden, haben gezeigt, dass eine Beziehung zwischen der schrittweisen Entwicklung einer Oberflächenkruste, Trockenrissen und der Dauer des Regen- 
falls besteht. Hingegen haben Regenexperimente an Smektit-armen Materialien keine ersichtliche Empfindlichkeit auf die Dauer des Niederschlags gezeigt. Diese Untersuchung hat ebenfalls deutlich gemacht, dass Smektit-reiches und Smektit-armes Festgestein unterschiedlich auf Feucht- und Trockenperioden reagieren. Der Einfluss von Trockenperioden wurde anhand der Smektit-reichen Materialien deutlich; hierbei hat die Hangorientierung eine direkte Auswirkung, aber auch andere, weitgreifendere Unterschiede, welche senso stricto bei saisonalen Klimaveränderungen vorkommen, haben einen Einfluss.

Schlüsselwörter: Badlands, Umweltwandel, Gesteinseigenschaften, Tonmineralogie

\section{Résumé: Badlands et changement environnemental}

Les badlands se développent dans des régions climatiques diverses ainsi que sur un grand nombre de types de sols et de soubassements rocheux. Le facteur déclencheur du développement des badlands peut être naturel (activité tectonique et changements climatique) mais le plus fréquemment, il est produit par l'activité humaine, à travers la dénudation des terres produite par un changement d'affectation des sols. Ce travail démontre clairement que la minéralogie de l'argile ainsi que le type et la quantité d'argile dans le soubassement rocheux jouent un rôle critique dans le développement des surfaces de croûte, dans la morphologie des bassins versants et finalement dans la formation de badlands. Les expériences menées en laboratoire sur des échantillons riches en smectite, sujets à des simulations de pluie, ont montré une corrélation entre les différentes phases du développement des croûtes de surface, les crevasses de dessiccation et la durée des pluies. De similaires expérimentations menées sur des échantillons pauvres en smectite n'ont montré aucune sensibilité à la durée de la pluviosité. Cette étude montre également que les lithologies riches ou pauvres en smectite répondent différemment aux périodes humides et sèches. L'importance des périodes sèches a été clairement démontrée dans le cas des matériaux riches en smectite, avec des implications directes sur l'orientation de la pente, mais aussi sur de plus profondes différences qui surviennent dans des conditions de changements climatiques saisonniers au sens strict.

Mots-clés: badlands, changement environnemental, propriétés lithologiques, minéralogie des argiles

Prof. Dr. Milica Kasanin-Grubin, Faculty of Applied Ecology, Singidunum University, Bulevar kralja Aleksandra 79, 11000 Belgrade, Serbia.

e-mail:m.kasanin.grubin@utoronto.ca

\section{Manuskripteingang/received/manuscrit entré le} 15.10.2007

Annahme zum Druck/accepted for publication/accepté pour l'impression: 3.3 .2008 